\title{
Influence of Ploidy Levels on Phenotypic and Cytogenetic Traits in Maize and Zea perennis Hybrids
}

\author{
María del Carmen Molina ${ }^{1}$ and María Dina Garcia ${ }^{2}$ \\ ${ }^{1}$ Instituto Fitotécnico de Santa Catalina, Facultad de Ciencias Agrarias y Forestales, \\ Universidad Nacional de La Plata. CIGen (UNLP, CONICET, CIC). \\ Garibaldi 3400, CC4, 1836 Llavallol, Buenos Aires, República Argentina \\ ${ }^{2}$ Facultad de Ingeniería y Cíncias Agrarias, Universidad Nacional de Lomas de Zamora, \\ Ruta 4 km 2, CC95, 1832 Lomas de Zamora, Buenos Aires, República Argentina \\ Accepted December 14, 1998
}

\begin{abstract}
Summary The aim of this work was to analyse: a) the phenotypic and cytogenetic differences of Zea mays and Zea perennis hybrids $2 n=30$ and 40 ; $b$ ) the effect of colchicine on their chromosomes pairing in meiosis. The plant materials used for these studies were $Z$. mays $(\mathrm{Zm} 20) 2 \mathrm{n}=20$, Z. mays $(Z m 40) 2 n=40$ and $Z$. perennis $(Z p) 2 n=40$ and the hybrids $Z m 20 \times Z p$ (MP30) $2 n=30$ and $Z m 40 \times Z p$ (MP40) $2 n=40$. Some characteristics of $Z$. perennis such as rhizomes, distic ears, perennially and profuse tillering were only observed in MP40 plants. In the other hand, MP30 plants had maize like phenotype; they were annual, with 4 round ears and low tillering. Therefore, phenotypic expression of several traits depends upon the dose of genes from each parent in the hybrid. The genomic formulae proposed for these species and hybrids were $\mathrm{Zm20}$ : AmAm BmBm; Zm40: AmAmAmAm BmBmBmBm; Zp: ApApApAp Bp $B_{1} \mathrm{Bp}_{1} \mathrm{Bp}_{2} \mathrm{Bp}_{2}$; MP30: AmApAp Bp $\mathrm{Bp}_{2}$ Bm; MP40: $A m A m A p A p ~ B m B m B p_{1} B_{2}$. Prezigotene colchicine treatment increased the frequency of quadrivalents in $\mathrm{Zm} 20, \mathrm{Zp}$ and Mp40 and trivalents in MP30. These results suggest homoeology between $\mathrm{Bm}$ and $\mathrm{Bp}_{1} \mathrm{Bp}_{2}$ genomes from maize and $\mathrm{Zp}$, respectively.
\end{abstract}

Key words Zea, Maize hybrids, Genomic formulae, Ploidy, Embryo rescue.

Zea is an important genus of the tribe Maydeae. According to Doebley and Iltis (1980) and Iltis and Doebley (1980) it is composed of 2 sections: Section Luxuriantes, which includes the annual $Z$. luxurians and the perennials $Z$. diploperennis and $Z$. perennis and Section Zea comprises only an annual species (Z. mays L.) which can be divided into three subspecies: $Z$. mays ssp. mays, $Z$. mays ssp. mexicana and $Z$. mays ssp. parviglumis. All the species mentioned above have $2 \mathrm{n}=20$ chromosomes except $Z$. perennis which has $2 n=40$.

In previous works, Molina and Naranjo (1987), Naranjo et al. (1990, 1994), Poggio et al. (1990) and Molina and García (1994) obtained cytological evidence supporting a polyploid condition for $2 \mathrm{n}=20$ for the taxa of the genus Zea, and proposed the genomic formulae for them. Moore et al. (1995) confirmed that maize is a complete tetraploid, although there are two separate genomes. Most of the larger chromosomes $(1,2,3,4,6)$ arrange a genome and the remaining shorter ones $(5,7,8,9,10)$ arrange another.

Thomas and Kaltsikes (1977) and Thomas and Ingram (1987) demonstrated that a dilute solution of colchicine applied to the outset of meiosis promotes the formation of multivalents from bivalents. Jackson and Murray (1983) suggested that colchicine can disrupt the genetically controlled position of the genomes promoting intergenomic pairing and revealing criptic homology in amphidiploids. Furthermore, pairing between heterologous chromosomes was observed in rye after dilute colchicine treatment. This could be due to a homology segment shared by those chromosomes (Puertas et al. 1984).

Maize and Z. perennis showed criptic homology when cells were treated in pre-zygotene with diluted colchicine during a $12 \mathrm{~h}$ period. Quadrivalents appeared in maize and its number increased 
in $Z$. perennis. These results support the allotetraploid nature of the genus Zea and suggests a basic genome $\mathrm{x}=5$ (Poggio et al. 1990). It is also suggested that the genus has homoeologous genomes that probably do not pair when a $\mathrm{Ph}$ like gene is present.

The purpose of this work was to analyze the phenotypic and cytogenetic behaviour of hybrids between Zea mays and Z. perennis with different ploidy levels as well as the effect of premeiotic treatment with diluted colchicine solutions on the meiotic behaviour.

\section{Materials and methods}

The plant materials used for these studies were Zea mays spp. mays cv. "Colorado Klein" (Zm20) $2 \mathrm{n}=20$, the maize inbreeds $2 \mathrm{n}=40(\mathrm{Zm} 40) \mathrm{N} 103 \mathrm{~A}, \mathrm{~N} 104 \mathrm{~B}, \mathrm{~N} 107 \mathrm{C}, \mathrm{N} 107 \mathrm{~B}$, and 902189-2190 supplied by the Maize Genetics Coop. Stock Center (Urbana, Illinois, USA); Zea perennis (Zp) $2 n=40$, from Ciudad Guzmán Jalisco, México, demised by Dr. Prywer and grown since then at the Instituto Fitotécnico de Santa Catalina. The hybrids studied were MP30 (Z. mays cv. “Colorado Klein" $\times Z$. perennis) $2 \mathrm{n}=30$ and MP40 (Z. mays $\mathrm{N} 107 \mathrm{~B} \times Z$. perennis and $\mathrm{N} 107 \mathrm{C} \times Z$. perennis) $2 \mathrm{n}=40$.

MP30 hybrid plants were obtained through embryo rescue. In autumn, maize silks were cut off to 2 and $3 \mathrm{~cm}$ and pollinated with Zp. Two days after pollination, the maize ears were sprayed with a $0.45 \mathrm{mM}$ 2,4-dichlorophenoxiacetic acid (2,4-D) solution (Furini and Jewel 1995) to help grain formation. The ears were harvested 21 days after pollination and caryopsis were disinfected with a $2.5 \%$ sodium hypochlorite solution. Embryos with a maximum length of $0.5 \mathrm{~mm}$ were plated on the basic medium of García and Molina (1992) supplemented with $4.5 \mu \mathrm{mol} \mathrm{L}^{-1} 2,4-\mathrm{D}$ and then incubated at $28-30^{\circ} \mathrm{C}$ with a $16 \mathrm{~h}$ photoperiod. Plants were regenerated on 2,4-D free medium.

The colchicine treatment was done according to Poggio et al. (1990). The stems were cut under a dilute solution of colchicine $\left(0.5 \times 10^{-4} \mathrm{M}\right)$ and kept therein for $12 \mathrm{~h}$. Before anthers fixation, the stems were placed in tap water during $24 \mathrm{~h}$. Control materials were fixed in $3: 1$ (absolute ethanol: acetic acid) solution.

Anthers were squashed in 2\% acetic haematoxyline (Nuñez 1968). The pairing configuration was determined at diakinesis (metaphase I). Only cells with well spread plates were scored.

\section{Results}

Only two caryopsis developed on one cv. "Colorado Klein" ear were obtained when Zm20 was outcrossed by Zp. Twenty one days after pollination these caryopsis showed deficient endosperm development and their embryos had a length of $0.5 \mathrm{~mm}$. Both embryos gave rise to green organogenic calli. Five plants with profuse radicular systems were regenerated over a 5 months period.

The number of developed caryopsis changed significantly according to the maize genotype used as female parent (Table 1). The best results were undoubtedly attained with the inbred N107C. Furthermore when the reciprocal crosses were done inbred $\mathrm{N107C}$ was the only one that induced

Table 1. Results of crossing different maize inbreeds $(2 \mathrm{n}=40)$ with $\mathrm{Zp}$

Maize genotype Pollinated ears Developed caryopsis Hybrid seed germination (\%) Hybrid pollen fertility (\%)

\begin{tabular}{lrrrc}
\hline N 103 A & 10 & 0 & 0 & 0 \\
N 104 B & 10 & 39 & 0 & 0 \\
N 107 B & 10 & 400 & 20 & $50-60$ \\
N 107 C & 10 & 2450 & 100 & $70-90$ \\
$90-2189 / 2190$ & 10 & 0 & 0 & 0 \\
\hline
\end{tabular}


Table 2. Pollen fertility and phenotypic differences of $\mathrm{Zm} \times \mathrm{Zp}$ hybrids with different ploidy levels

\begin{tabular}{|c|c|c|}
\hline & MP30 & MP40 \\
\hline 1. & Perennial & 1. Annual of Biennial \\
\hline 2. & Seeds viability $=1 \%$ & 2. Seeds viability $=70-90 \%$ \\
\hline 3. & Pollen fertility $=3-5 \%$ & 3. Pollen fertility $=70-95 \%$ \\
\hline 4. & $\begin{array}{l}\text { Distic ears. The rachis dissarticulates at maturity } \\
\text { scattering the seeds. }\end{array}$ & $\begin{array}{l}\text { 4. Small } 2 \text { to } 4 \text { rowed ears. Nacked seeds disposed on a } \\
\text { rigid rachis. }\end{array}$ \\
\hline 5. & Average number of tillers $/$ plant $=20$ & 5. Average number of tillers/plant $=4$ \\
\hline 6. & Short and defined rhizomes & 6. No rhizomes \\
\hline 7. & $\begin{array}{l}\text { Flowering response to photoperiod: short day } \\
\text { qualitative }\end{array}$ & $\begin{array}{l}\text { 7. Flowering response to photoperiod: short day } \\
\text { quantitative. }\end{array}$ \\
\hline 8. & Multiplication through rhizomes. & 8. Cannot be multiply asexually \\
\hline 9. & Does not hybridise naturally & 9. Naturally hybridise to some maize genotypes \\
\hline 10. & Shows clorantia under stress conditions & 10. Does not show clorantia \\
\hline
\end{tabular}

the development of viable hybrid seeds.

Ploidy level or the number of chromosomes contributed by each parent, notably affected the phenotype of the hybrid plants (Table 2, Fig. 1).

The most frequent meiotic configurations observed in diakynesis-metaphase I (Table 3) were the following:

$\mathrm{Zm} 20$ (Table 3, Fig. 2A). A $100 \%$ of the analysed cells showed 10II. Secondary association, separation of the chromosomes in two groups of 5 each and an average of 14 chias$\mathrm{ma} /$ cell were observed in a $40 \%$ of the cells. Molina and Naranjo (1987), Naranjo et al. (1990) according to cytogenetic studies fulfilled in $\mathrm{Zm} 20, \mathrm{Zp}, \mathrm{Z}$. diploperennis and their hybrids proposed a basic chromosome number $\mathrm{x}=5$ for genus Zea and the genomic formulae AmAm BmBm for $\mathrm{Zm} 20$.

$\mathrm{Zm} 40$ (Table 3) revealed 10IV (30\%) and 9 IV +2II (23.94\%) with an average of 8.34IV+3.24II and 33.75 chiasma/cell. According to these results and the fact that the basic number for the genus Zea is $\mathrm{x}=5$, it is proposed for $\mathrm{Zm} 40$ the genomic formulae AmAmAmAm BmBmBmBm.

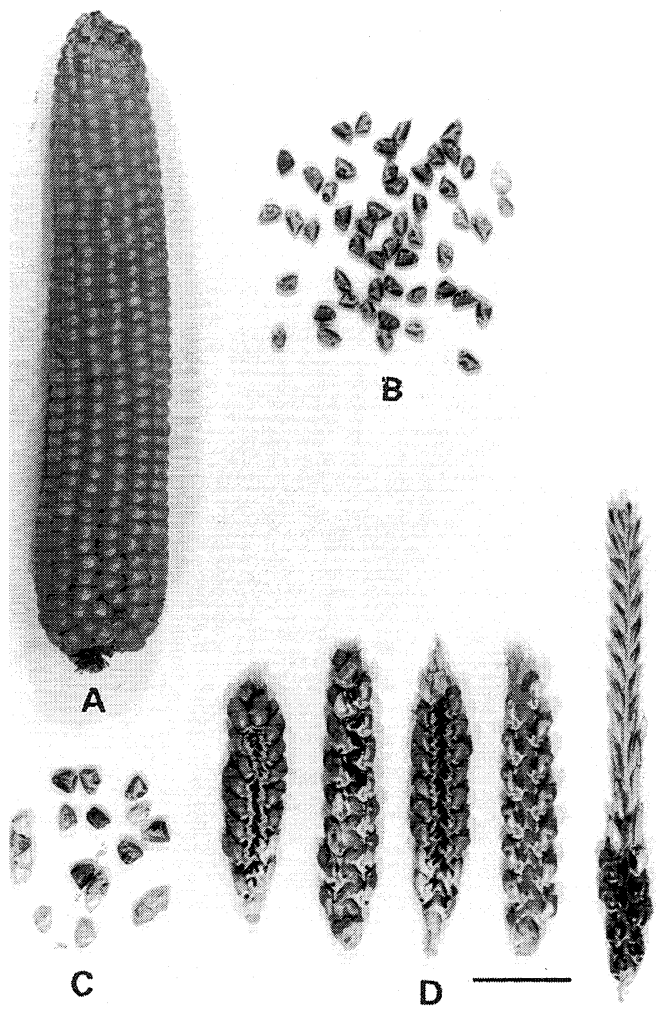

Fig. 1. Ears of Z. mays, Z. perennis and their hybrids: A) $\mathrm{Zm}$; B) Zp; C) MP30; D) MP40. Scale $=3 \mathrm{~cm}$.

Zp (Table 3, Fig. 2B) shown 5IV+10II $(54.47 \%)$ and $4 \mathrm{IV}+12 \mathrm{II}(20.15 \%)$. Only in a $5 \%$ of the cells more than $5 \mathrm{IV}$ were observed with an average of 4.44IV+11.02II. The average number of chiasma/cell was 15.69 in bivalents and 18.87 in tetravalents with a whole of 34.56. The most frequent chromosomic pairing found in $\mathrm{Zp}$ suggests for this species the genomic formulae ApApApAp $\mathrm{Bp}_{1} \mathrm{Bp}_{1} \mathrm{Bp}_{2} \mathrm{Bp}_{2}$.

Hybrid MP30 (Table 3, Fig. 2C) had 5III+5II+5I (53.71\%) and 4III+6II+6I (25.71\%) with an average/cell of $4.71 \mathrm{III}+5.39 \mathrm{II}+5.07 \mathrm{I}$. More than $5 \mathrm{IV}$ were observed just in a $6 \%$ of the cells, being the average number of chiasma/cell $=23.06$. The trivalents were arranged by the pairing of 
Table 3. Meiotic configurations of Zea species and $\mathrm{F}_{1}$ studied

\begin{tabular}{|c|c|c|c|c|c|c|c|}
\hline \multirow{2}{*}{$\begin{array}{l}\text { Species and } \\
\text { hybrids }\end{array}$} & \multirow{2}{*}{$2 n$} & \multicolumn{4}{|c|}{ diakinesis-metaphase configurations } & \multirow{2}{*}{$\%$} & \multirow{2}{*}{ No. of cells studied } \\
\hline & & I & II & III & IV & & \\
\hline $\mathrm{Zm} 20$ & 20 & & 10 & & & 100 & 200 \\
\hline \multirow[t]{13}{*}{$\mathrm{Zm} 40$} & 40 & & 0 & & 10 & 30.28 & 142 \\
\hline & & & 2 & & 9 & 23.94 & \\
\hline & & & 4 & & 8 & 16.90 & \\
\hline & & & 6 & & 7 & 10.52 & \\
\hline & & & 8 & & 6 & 7.75 & \\
\hline & & & 10 & & 5 & 4.23 & \\
\hline & & & 12 & & 4 & 0.70 & \\
\hline & & & 14 & & 3 & 1.40 & \\
\hline & & 1 & 6 & 1 & 6 & 0.70 & \\
\hline & & 1 & 8 & 1 & 5 & 0.70 & \\
\hline & & 1 & & 1 & 9 & 1.40 & \\
\hline & & 1 & 2 & 1 & 8 & 1.40 & \\
\hline & & $\overline{\mathrm{X}}=0.04$ & 3.24 & 0.04 & 8.34 & & \\
\hline \multirow[t]{14}{*}{$\mathrm{Zp}$} & 40 & & 18 & & 1 & 1.49 & 1.34 \\
\hline & & & 16 & & 2 & 3.73 & \\
\hline & & & 14 & & 3 & 6,72 & \\
\hline & & & 12 & & 4 & 20.15 & \\
\hline & & & 10 & & 5 & 54.47 & \\
\hline & & & 8 & & 6 & 5.22 & \\
\hline & & 1 & 16 & 1 & 1 & 0.75 & \\
\hline & & 2 & 15 & & 2 & 0.75 & \\
\hline & & 2 & 13 & & 3 & 0.75 & \\
\hline & & 2 & 11 & & 4 & 2.98 & \\
\hline & & 1 & 10 & 1 & 4 & 0.75 & \\
\hline & & 2 & 9 & & 5 & 1.49 & \\
\hline & & 4 & 8 & & 5 & 0.75 & \\
\hline & & $\overline{\mathrm{X}}=0.16$ & 11.02 & 0.01 & 4,44 & & \\
\hline \multirow[t]{10}{*}{ MP30 } & 30 & 7 & 7 & 3 & & 2.14 & 140 \\
\hline & & 6 & 6 & 4 & & 25.71 & \\
\hline & & 4 & 7 & 4 & & 5.00 & \\
\hline & & 7 & 4 & 5 & & 1.43 & \\
\hline & & 5 & 5 & 5 & & 53.57 & \\
\hline & & 3 & 6 & 5 & & 5.71 & \\
\hline & & 1 & 7 & 5 & & 0.71 & \\
\hline & & 4 & 4 & 6 & & 5.00 & \\
\hline & & 4 & 3 & 7 & & 0.71 & \\
\hline & & $\bar{X}=5.07$ & 5.39 & 4.71 & & & \\
\hline \multirow[t]{16}{*}{ MP40 } & 40 & & 20 & & 0 & 0.45 & 224 \\
\hline & & & 18 & & 1 & 3.12 & \\
\hline & & & 16 & & 2 & 8.48 & \\
\hline & & & 14 & & 3 & 16.96 & \\
\hline & & & 12 & & 4 & 21.43 & \\
\hline & & & 10 & & 5 & 27.23 & \\
\hline & & 1 & 16 & 1 & 1 & 0.45 & \\
\hline & & 1 & 8 & 1 & 5 & 2.23 & \\
\hline & & 1 & 12 & 1 & 3 & 2.23 & \\
\hline & & 2 & 11 & & 4 & 0.45 & \\
\hline & & 2 & 9 & & 5 & 2.23 & \\
\hline & & 2 & 7 & & 6 & 0.45 & \\
\hline & & 2 & 13 & & 3 & 1.80 & \\
\hline & & 4 & 12 & & 3 & 0.45 & \\
\hline & & 2 & 7 & & 6 & 0.45 & \\
\hline & & $\bar{X}=0.20$ & 11.62 & 0.03 & 4.12 & & \\
\hline
\end{tabular}



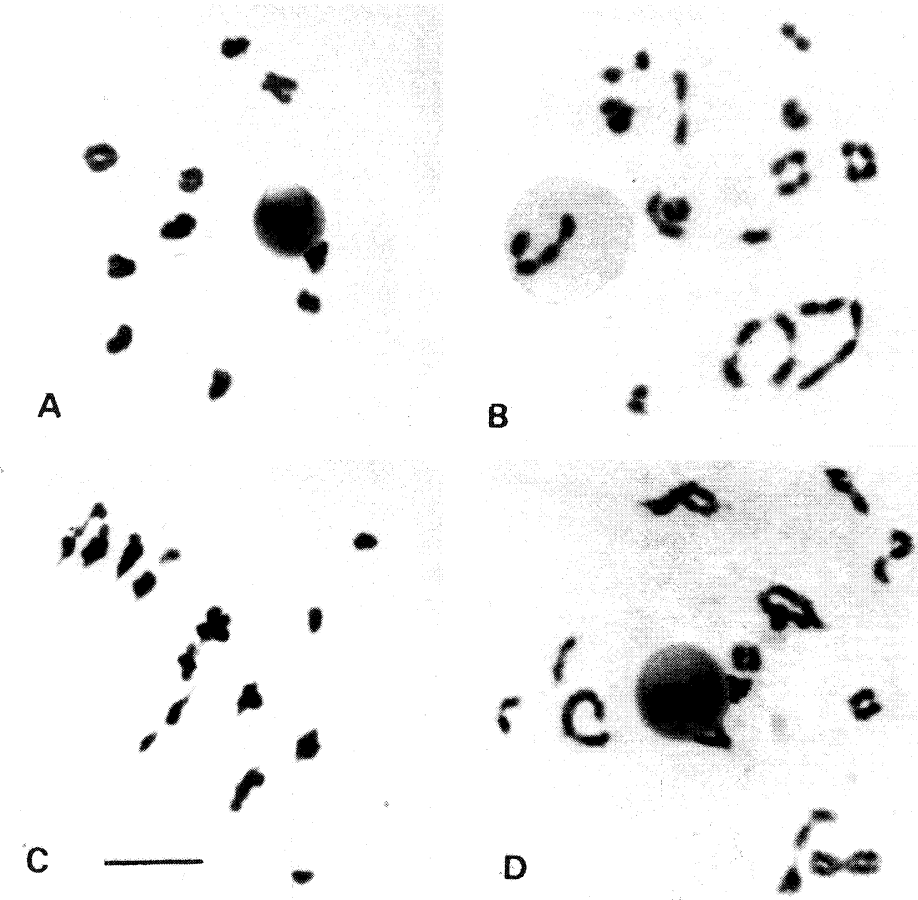

Fig. 2. Meiotic configurations observed in diakynesis-metaphase I in A) $\mathrm{Zm} 20$ (10II); B) $\mathrm{Zp}(51 \mathrm{~V}+$ 10II); C) MP30 (5III+5II+5I); D) MP40 (5IV+10II). Scale $=10 \mu \mathrm{m}$.
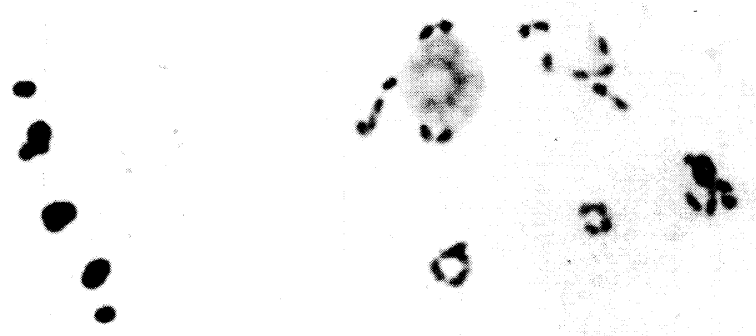

A

B

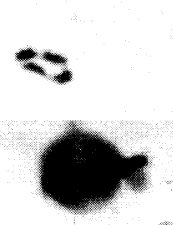

$2 \%$,
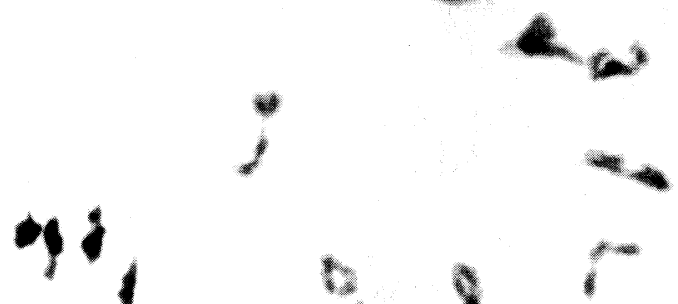

C

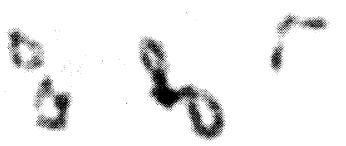

Fig. 3. Meiotic configurations induced by colchicine treatment in: A) Zm20 (5IV); B) Zp (8IV+4II); C) MP30 (10III); D) MP40 (9IV+2II). Scale $=10 \mu \mathrm{m}$. 
one $\mathrm{Zm} 20$ chromosome with two $\mathrm{Zp}$ chromosomes (AmApAp). The bivalents were the result of the pairing among the homoeologous chromosomes of $\mathrm{Zp}\left(\mathrm{Bp}_{1} \mathrm{Bp}_{2}\right)$ and the univalents were the chromosomes of $\mathrm{Zm} 20(\mathrm{Bm})$. The genomic formulae proposed for the hybrid MP30 is AmApAp $\mathrm{Bp}_{1} \mathrm{Bp}_{2} \mathrm{Bm}$.

Hybrid MP40 (Table 3, Fig. 2D) had 5IV+10II (27.23\%) and 4IV+12II (21.43\%) with an average of $4.12 \mathrm{IV}+11.62 \mathrm{II}$ per cell. More than 5IV were observed only in a $1 \%$ of the cells. The average of chiasma per cell was 33.59. The genomic formulae proposed is AmAmApAp BmBm $\mathrm{Bp}_{1} \mathrm{Bp}_{2}$.

The effects of colchicine treatment on the meiotic configurations of analysed species and hybrids are shown in Figs. 3-5. Control Zm20 plants formed only bivalents, but treated plants showed at least one quadrivalent in the $61 \%$ of the cells, with a maximum of $5 \mathrm{IV}$ in the $11 \%$ of the cells (Figs. 3A, 4a). In $\mathrm{Zm} 20$, colchicine promoted pairing between homoeologous chromosomes from both genomes of $\mathrm{Zea}(\mathrm{AmAm} \mathrm{BmBm})$. It was also observed an enlargement of the chiasma average number, from 14 (control) to 20 (treated) per cell.

$\mathrm{Zm} 40$ treated plants showed a little increase of quadrivalents if compared to control plants, but the difference was not significant. Neither hexavalents nor octovalents were observed (Fig. 4b).

In $\mathrm{Zp}$ (Figs. 3B, 4c), colchicine treatment induced a remarkable increase of the average number of IV per cell, from 4.44IV (control) to 5.83IV (treated) up to a maximum of 10IV per cell. In this case, the increment of quadrivalents would be due to the pairing induction amongst homoeologous chromosomes that normally do not pair. The average number of chiasma/cell is 41.80 , a $21 \%$ higher than control plants.

In the hybrid MP40 (Figs. 3C, 4d) a remarkable increase in the number of IV was observed in treated plants $(\overline{\mathrm{X}}=5.24)$ if compared to control plants $(\overline{\mathrm{X}}=4.12)$. In this case, the increment in the number of IV would be due to pairing between homoeologous genomes of both species $(\mathrm{BmBm}$ $\left.\mathrm{Bp}_{1} \mathrm{Bp}_{2}\right)$.

In the hybrid MP30 (Figs. 3D, 5) a highly significant increase of III was observed in the treated material $(\overline{\mathrm{X}}=7.85)$ when compared to control plants $(\overline{\mathrm{X}}=4.71)$. The colchicine treatment induced pairing of homoeologous genomes from both species $\left(\mathrm{BmBm} \mathrm{Bp} \mathrm{Bp}_{2}\right)$ which notably increased the percentage of trivalents and the number of chiasma/cell from 23.06 (control) to 27.09 (treated).

\section{Discussion}

$\mathrm{Zm} 40$ and $\mathrm{Zp}$ hybridize without restrictions under natural conditions. Their hybrids have meiotic regularity and fertile offspring. On the other hand, crossings between $\mathrm{Zm} 20$ and $\mathrm{Zp}$ only yield 0.1 to $1 \%$ of viable seeds. Although a few hybrid caryopsis developed until 21 days after fecundation, the endosperm collapses becoming in the abortion of the embryos. This problem can be overcome through rescue and in vitro culture of the immature embryos.

Z. mays and Z. perennis hybrid phenotypes differ according to their chromosome number (Table 2). This fact suggests that phenotypic expression of several traits depends upon the dose of genes from each parent in the hybrid. This would explain the great variability observed in the next generations (Molina 1978).

Genetic, cytogenetic and biochemical studies provided enough evidence to suggest that the genus Zea has a basic chromosome number $\mathrm{x}=5$ and that $\mathrm{Zm} 20$ is an allotetraploid with two homoeologous genomes Am and Bm (Rhoades 1951, Ghatnekar 1965, Vijendra Das 1970, Gottlieb 1982, Bennett 1983, 1984, Molina and Naranjo 1987, Naranjo et al. 1990). The maize Am genome five chromosomes pair arranging II with the homoeologous Bm chromosomes only when their respective homologous are not present in the cell, as for example during diakynesis-metaphase I of haploid plants (Mc Clintock 1933, Chaganti 1965, Ting 1966, 1969).

According to Molina and Naranjo (1987), Zp has 3 genomes $\mathrm{Ap} \mathrm{Bp}$ and $\mathrm{Bp}_{2}$. The Ap genome 

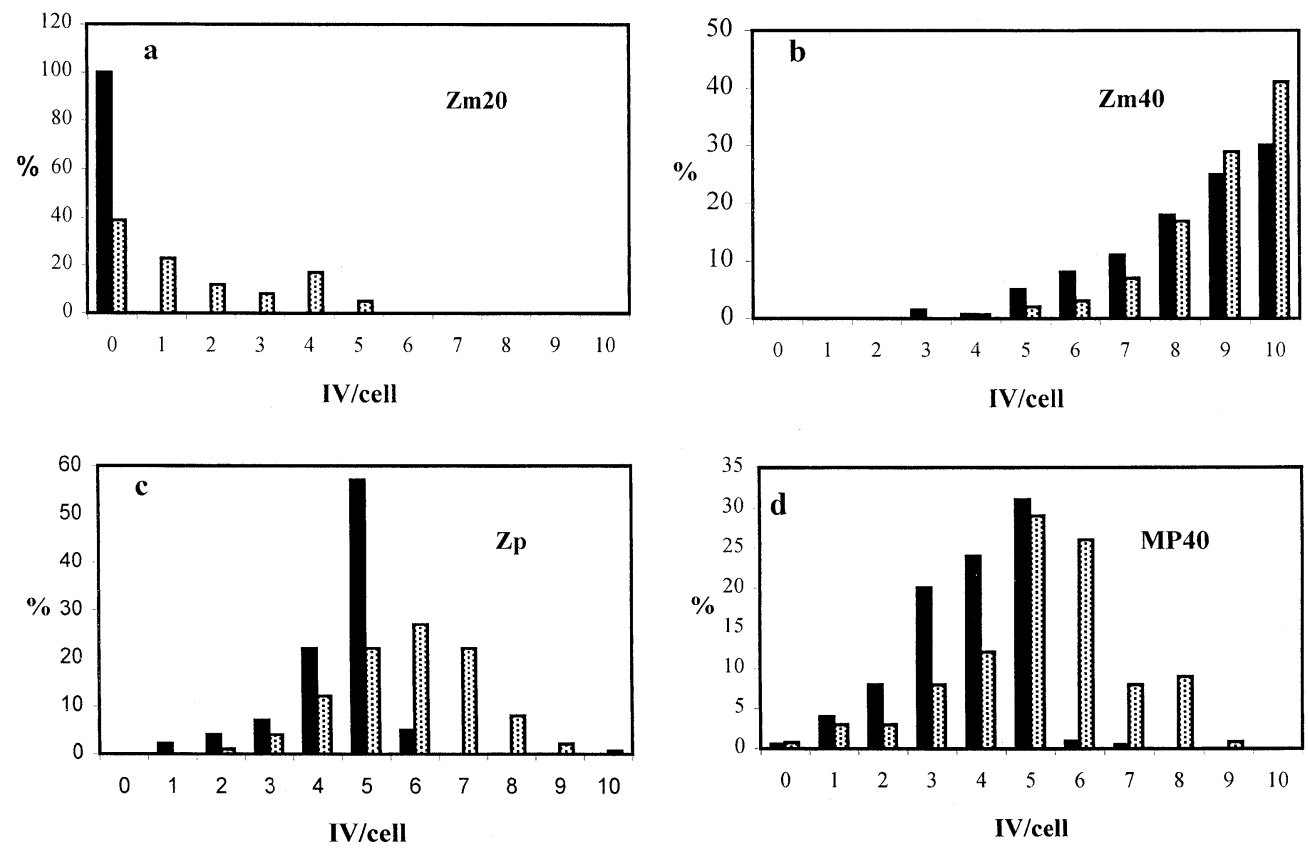

Guntreated plants $\quad$ treated plants

Fig. 4. Number of IV/cell in colchicine $\left(0.5 \times 10^{-4} \mathrm{M}\right)$ treated and control plants of a) $\mathrm{Zm} 20$, b) $\mathrm{Zm} 40$, c) $\mathrm{Zp}$ and d) MP40.

pairs building $5 \mathrm{IV}$ whilst $\mathrm{Bp}_{1}$ and $\mathrm{Bp}_{2}$ genomes are homoeologous and pair between them only when their respective homologous are not present in the nucleus as it is observed in the hybrids MP30 and MP40. Otherwise it was seen that A genomes from maize and $\mathrm{Zp}$ pair arranging trivalents (AmApAp) or quadrivalents (AmAmApAp) depending if the hybrid is $2 n=30$ or 40 , respectively. The chromosomes shared by both species are 1,2, 3, 4 and 6 from maize and 1-2, 3-4, 7-8, 9-10 and 13-14 from Zp (Molina 1986). Jackson and Murray (1983) demonstrated that the application of a dilute solution of colchicine $\left(0.5 \times 10^{-4} \mathrm{M}\right)$ during pre-meiosis promotes intergenomic pairing and reveals cryptic homology. With this technique, Poggio et al. (1990) and Naranjo et al. (1994) confirmed the existence of cryptic homology and the polyploid nature of $\mathrm{Zm} 20, \mathrm{Zp}$ and the hybrids between $\mathrm{Zp}$ and $Z$. diploperennis $(2 \mathrm{n}=30-40)$. The $11 \%$ of the $\mathrm{Zm} 20$ cells showed 5IV, which points out that all the Am and Bm homoeologous chromosomes pair in these cells (Figs. 4a, 3A). All the opposite, colchicine treatment did not promote any significant increase in the number of quadrivalents per cell in Zm40 (Fig. 4b).

Colchicine treated $\mathrm{Zp}$ plants showed a significant increase in the number of quadrivalents per cell because of $\mathrm{Bp}_{1}$ and $\mathrm{Bp}_{2}$ genomes pairing (Fig. $4 \mathrm{c}$ ). In $\mathrm{Zm}$ and $\mathrm{Zp}$ hybrids, colchicine treatment notably increased the number of III (MP30) and IV (MP40) per cell because of pairing between Bm genome from maize and $\mathrm{Bp}_{1} \mathrm{Bp}_{2}$ genomes from $\mathrm{Zp}$. This confirms that $\mathrm{Bm}$ and $\mathrm{Bp}_{1} \mathrm{Bp}_{2}$ genomes are homoeologous. 


\section{Conclusions}

Beginning with the study of the hybrids between $\mathrm{Zm}$ with two ploidy levels $(2 \mathrm{n}=20$ or 40$)$ and $\mathrm{Zp}$, the following statements can be expressed:

Both species naturally outcross whether they have the same chromosome number therefore they show chromosome compatibility.

The plant phenotype is determined by the dose of genes donoured by each parent to the hybrid.

The colchicine treatment reveals cryptic homology between $\mathrm{Bm}$ genome from maize and $\mathrm{Bp}_{1}$ $\mathrm{Bp}_{2}$ genomes from $\mathrm{Zp}$.

\section{Acknowledgements}

The authors are grateful to Ing. Agr. Víctor R. Corcuera for critical reading of the manuscript. This work was supported by CONICET, Universidad Nacional de La Plata and Universidad Nacional de Lomas de Zamora.

\section{References}

Bennett, M. D. 1983. The Spatial Distribution of Chromosomes. In: Brandham, P. E. and Bennett, M. D. (eds.) Kew Chromosome Conf. II Allen and Unwin, London, pp. 71-90.

- 1984. The Genome, the Natural Karyotype and Biosystematics. In: Grant, W. F. (ed.) Plant Biosystematics. Academic Press, New York, pp. 41-66.

Chaganti, R. S. K. 1965. Cytogenetic Studies of Maize-Tripsacum Hybrids and Their Derivatives. The Bussey Institution, Harvard University, $93 \mathrm{pp}$.

Doebley, J. F. and Iltis, H. H. 1980. Taxonomy of Zea. I Subgeneric classification with key to taxa. Am. J. Botany 67: 982-993.

Furini, A. and Jewell, C. 1995. Somatic embryogenesis and plant regeneration of maize/Tripsacum hybrids. Maydica 40: $205-210$.

García, M. D. and Molina, M. del C. 1992. La regeneración de plantas de maíz (Zea mays ssp. mays) a partir del cultivo de tejidos y su aplicación en el mejoramiento genético. Rev. de la Fac. de Agron. de la U.N.L.P. 68: 15-25.

Ghatnekar, M. V. 1965. Spontaneous chromosome aberrations and abnormal behaviour in italian maize populations. Cytologia 30: 426-435.

Gottlieb, L. D. 1982. Conservation and duplication of isozymes in plants. Science 216: 373-380.

Iltis, H. H. and Doebley, J. F. 1980. Taxonomy of Zea (Gramineae) 2. Subspecific categories in the Zea mays complex and generic synopsis. Am. J. Botany 67: 994-1004.

Jackson, R. C. and Murray, B. G. 1983. Colchicine induced quadrivalent formation in Helianthus: evidence of ancient polyploidy. Theor. Appl. Genet. 64: 219-222.

Mc Clintock, B. 1933. The association of non-homologous parts of chromosomes in the midprophase of meiosis in Zea mays. Z. Zellforsch Mikroskanat 19: 191-237.

Molina, M. del C. 1978. Estudios citogenéticos del híbrido intergenérico Euchlaena perennis Hitch por Zea mays. Rev. de la Fac. de Agron. de La Plata 54(2): 521-578.

- 1986. Estudio citogenético de Zea perennis. Genética Ibérica 38: 27-45.

- and Naranjo, C. A. 1987. Cytogenetic studies in the genus Zea. 1. Evidence for five as the basic chromosome number. Theor. Appl. Genet. 73: 542-550.

- and García, M. D. 1994. Estudio citogenético de un hexaploide $(2 \mathrm{n}=30)$ de Zea mays. XXV Congreso Argentino de Genetica. Res. 26.

Moore, G., Davos, K. M., Wang, Z. and Gale, M. D. 1995. Grasses, line up and form a circle. Curr. Biol. 5(7): 737-739.

Naranjo, C. A., Molina, M. C. and Poggio, L. 1990. Evidencias de un número básico $\mathrm{x}=5$ en el género Zea y su importancia en estudios del origen del maíz. Acad. Nac. Cs. Fís. Nat., Buenos Aires, Monografía 5: 43-53.

- Poggio, L., Molina, M. del C. and Bernatené, E. A. 1994. Increase in multivalents frequency in F1 hybrids of Zea diploperennis $\times Z$. perennis by colchicine treatment. Hereditas 120: $241-244$.

Nuñez, O. 1968. An acetic haematoxylin squash method for small chromosomes. Caryologia 21: 115-119.

Poggio, L., Molina, M. C. and Naranjo, C. A. 1990. Cytogenetics studies in the genus Zea. 2. Colchicine-induced multivalents. Theor. Appl. Genet. 79: 461-464.

Puertas, M. J., De La Peña, A., Estades, B. and Merino, E. 1984. Early sensibility to colchicine in developing anthers of rye. 
Chromosoma 89: 121-126.

Rhoades, M. M. 1951. Duplicate genes in maize. Am. Nat. 85: 105-110.

Thomas, J. B. and Kaltsikes, P. J. 1977. The effect of colchicine on chromosome pairing. Can. J. Genet. Cytol. 19: $231-249$.

Thomson, A. M. and Ingram, R. 1987. The control of chiasma formation in colchicine treated meiocytes of Senecio squalidus. Heredity 59: 353-354.

Ting, Y. C. 1966. Duplications and meiotic behaviour of the chromosomes in haploid maize (Zea mays L.). Cytologia 31: 324-329.

- 1969. Fine structure of the meiotic first prophase chromosomes in haploid and diploid maize. Genetics (Supl.)/(Abstr.) 62: 58 .

Vijendra Das, L. D. 1970. Chromosome associations in diploid and autotetraploid Zea mays L. Cytologia 35: 259-261. 